\title{
Integrin $\alpha_{v} \beta_{6}$ Is an RGD-Dependent Receptor for Coxsackievirus A9
}

\author{
Çiğdem H. Williams, ${ }^{1}$ Tommi Kajander, ${ }^{2}$ Timo Hyypiä, ${ }^{2,3}$ Terry Jackson, ${ }^{4}$ \\ Dean Sheppard, ${ }^{5}$ and Glyn Stanway ${ }^{1 *}$

\begin{abstract}
Department of Biological Sciences, University of Essex, Colchester CO4 3SQ, ${ }^{1}$ and Department of Molecular Biology, Institute for Animal Health, Pirbright, Surrey GU24 ONF, ${ }^{4}$ United Kingdom; Haartman Institute, Department of Virology, University of Helsinki, FIN-00014 Helsinki, ${ }^{2}$ and Department of Medical Microbiology, University of Oulu, FIN-90014 Oulu, ${ }^{3}$

Finland; and Lung Biology Center, Department of Medicine, San Francisco General Hospital, and Division of Pulmonary and Critical Care Medicine, Department of Medicine, University of California, San Francisco, California $94143^{5}$
\end{abstract}

Received 27 October 2003/Accepted 24 February 2004

\begin{abstract}
Coxsackievirus A9 (CAV9), a member of the Enterovirus genus of Picornaviridae, is a common human pathogen and is one of a significant number of viruses containing a functional arginine-glycine-aspartic acid (RGD) motif in one of their capsid proteins. Previous studies identified the RGD-recognizing integrin $\alpha_{\mathrm{v}} \beta_{3}$ as its cellular receptor. However, integrin $\alpha_{v} \beta_{6}$ has been shown to be an efficient receptor for another RGDcontaining picornavirus, foot-and-mouth disease virus (FMDV). In view of the similarity in sequence context of the RGD motifs in CAV9 and FMDV, we investigated whether $\alpha_{\mathbf{v}} \beta_{6}$ can also serve as a receptor for CAV9. We found that CAV9 can bind to purified $\alpha_{v} \beta_{6}$ and also to SW480 cells transfected with $\beta_{6}$ cDNA, allowing expression of $\alpha_{\mathrm{v}} \beta_{6}$ on their surface, but it cannot bind to mock-transfected cells. In addition, a higher yield of CAV9 was obtained in $\beta_{6}$-expressing cells than in mock-transfected cells. There was no similar enhancement in infection with an RGD-less CAV9 mutant. We also found $\beta_{6}$ on the surface of GMK cells, a cell line which CAV9 infects efficiently by an RGD-dependent mechanism. Significantly, this infection is blocked by an antibody to $\alpha_{v} \beta_{6}$, while this antibody did not block the low level of infection by the RGD-less mutant. Thus, integrin $\alpha_{v} \beta_{6}$ is an RGD-dependent receptor for CAV9 and may be important in natural CAV9 infections.
\end{abstract}

Coxsackievirus A9 (CAV9), a member of the Enterovirus genus of the Picornaviridae family, is a common human pathogen that causes central nervous system infections and myocarditis as well as a range of milder illnesses $(11,43)$. The picornavirus particle is about $28 \mathrm{~nm}$ in diameter and consists of a naked capsid with icosahedral symmetry, surrounding a positive sense RNA genome of around 7,100 to 8,500 nucleotides (41). The capsid is made up of 60 copies of each of four proteins, VP1 to VP4, and interacts with receptors during the early stages of infection. A number of picornavirus receptors have been identified, and they include several integrins (9). Integrins are named for their role in integrating the intracellular cytoskeleton with the extracellular matrix and participate in a number of cell-cell, cell-matrix interactions. They are heterodimeric proteins with one $\alpha$ and one $\beta$ subunit, and each contains an exodomain, the site of interaction with ligands, a transmembrane region, and a cytoplasmic domain. The 8 known $\beta$ subunits and 14 known $\alpha$ subunits combine to give at least 21 different heterodimeric combinations $(16,38,40)$.

The arginine-glycine-aspartic acid (RGD) motif was the first integrin-binding sequence to be identified (38) and is recognized by several integrins $\left(\alpha_{5} \beta_{1}, \alpha_{8} \beta_{1}, \alpha_{\mathrm{IIb}} \beta_{3}, \alpha_{\mathrm{v}} \beta_{1}, \alpha_{\mathrm{v}} \beta_{3}, \alpha_{\mathrm{v}} \beta_{5}\right.$, $\alpha_{\mathrm{v}} \beta_{6}$ and $\left.\alpha_{\mathrm{v}} \beta_{8}\right)$. Picornaviruses from three diverse genera are known to contain an RGD motif that is involved in cell entry: foot-and-mouth disease viruses (FMDV) (Aphthovirus) (26), human parechoviruses (Parechovirus) $(5,10,17,42)$; echovirus

\footnotetext{
* Corresponding author. Mailing address: Department of Biological Sciences, University of Essex, Colchester CO4 3SQ, United Kingdom. Phone: 441206 873308. Fax: 441206 872592. E-mail: stanwg@essex.ac.uk.
}

9 (E9), and CAV9 (both Enterovirus) $(6,36,51)$. In the case of FMDV it is located in the prominent GH loop of VP1, whereas in the other viruses it is located close to the VP1 C terminus (14). Essentially all natural isolates of these viruses contain the $\operatorname{RGD}$ motif $(7,21,22,32,39,52)$, although laboratory-adapted or genetically engineered strains lacking the motif can be recovered and may grow well in some cell lines, indicating that alternative, RGD-independent entry pathways are being used $(2,8,15,24,50)$. For instance, a series of CAV9 deletion or substitution mutants lacking the RGD motif grow in several cell lines, such as GMK and A549, albeit inefficiently $(13,15)$. The mutants, including D4, which has a precise deletion of the RGD tripeptide, have unimpaired growth in RD cells, showing that this RGD-independent infection can be efficient in some cell lines. The RGD-independent receptor(s) has not been identified, and it is not known if the same molecule is used in these different cell lines.

One known RGD-recognizing integrin, $\alpha_{\mathrm{v}} \beta_{3}$, is reported to be involved in cell entry of E9, CAV9, FMDV, and parechoviruses $(3,18,23,32-35,37,44-46)$, but other species of integrins have also been implicated in infection by the latter two (19-21, 23, 35). Researchers have previously identified amino acid sequence identity between the residues flanking the RGD motif of CAV9 and part of latent transforming growth factor $\beta 1$ (TGF- $\beta 1$ ), later shown to be a ligand for integrin $\alpha_{\mathrm{v}} \beta_{6}(7$, 31). Moreover, FMDV has been shown to recognize $\alpha_{\mathrm{v}} \beta_{6}$, and this picornavirus shares the same consensus sequence, RGDM/ LXXL, seen in CAV9 isolates (27).

These observations prompted us to investigate the potential use of integrin $\alpha_{\mathrm{v}} \beta_{6}$ as a receptor by CAV9. Here we show that CAV9 binds to purified $\alpha_{\mathrm{v}} \beta_{6}$ and to $\alpha_{\mathrm{v}}$-containing cells trans- 
fected with the $\beta_{6}$ subunit. In addition, the presence of the $\beta_{6}$ chain greatly enhances susceptibility of the cells to CAV9 infection but not to infection by the RGD-less mutant D4, while antibody to $\alpha_{\mathrm{v}} \beta_{6}$ efficiently blocks infection in GMK cells. Thus, $\alpha_{\mathrm{v}} \beta_{6}$ is a functional RGD-dependent CAV9 receptor.

\section{MATERIALS AND METHODS}

Virus, cell lines, and media. CAV9 (Griggs strain) was purified by sucrose gradient centrifugation as previously described (6). RD cells were maintained in minimal essential medium (MEM) containing $10 \%$ fetal calf serum (FCS), $2 \%$ vitamins, $2 \%$ nonessential amino acids, and $100 \mu \mathrm{g}$ of gentamicin $/ \mathrm{ml}$. GMK cells were maintained in MEM containing $10 \%$ heat-inactivated FCS, $1 \%$ nonessential amino acids, and $100 \mu \mathrm{g}$ of gentamicin/ml. The human colon carcinoma cell line, SW480, transfected to express either the full-length human $\beta_{6^{-}}$or human $\beta_{3}$-integrin subunit and the mock-transfected cells (49), were cultivated in Dulbecco's modified Eagle medium (DMEM) supplemented with 10\% FCS (heat inactivated), $2 \mathrm{mM}$ glutamine, penicillin $(100 \mathrm{U} / \mathrm{ml})$, streptomycin $(100 \mu \mathrm{g} / \mathrm{ml})$, and $1 \mathrm{mg}$ of Geneticin (Invitrogen)/ml. CHO cells expressing soluble human $\alpha_{v} \beta_{6}$ (49) were grown in DMEM supplemented with $10 \%$ FCS, penicillin (100 $\mathrm{U} / \mathrm{ml})$, and streptomycin $(100 \mu \mathrm{g} / \mathrm{ml})$.

$\boldsymbol{\alpha}_{\mathbf{v}} \boldsymbol{\beta}_{6}$ purification. Soluble human $\alpha_{v} \beta_{6}$ was produced from transfected CHO cells as described previously (49). Briefly, the cells were grown in roller bottles, the medium was changed to serum-less DMEM, and the cells were incubated for $24 \mathrm{~h}$ at $37^{\circ} \mathrm{C}$. The medium was then collected, clarified by centrifugation, filtered, and concentrated by Centricon Plus-80 (Amicon). The integrin was bound to RGD-Sepharose, washed with Tris-buffered saline (TBS) (pH 7.4) supplemented with $1 \mathrm{mM} \mathrm{MgCl}, 1 \mathrm{mM} \mathrm{MnCl}_{2}$, and $2 \mathrm{mM} \mathrm{CaCl}_{2}$, and eluted with TBS containing $10 \mathrm{mM}$ EDTA by overnight incubation. The yield was usually 5 to 20 $\mu \mathrm{g}$ per roller bottle. The identity of the isolated material was confirmed by blotting, performed as described previously (49). The $\alpha_{v}$ chain was recognized by using a polyclonal antibody to $\alpha_{v} \beta_{3}$ (AGK4; a kind gift from Merja Roivainen) and a specific $\alpha_{v}$ monoclonal (L230; American Type Culture Collection), and the $\beta_{6}$ chain was recognized by a $\beta_{6}$-specific monoclonal antibody (clone $\operatorname{CS} \beta 6$, MAB2076Z; Chemicon). No signal was seen when the blots were probed with specific $\beta_{3}$ or $\alpha_{v} \beta_{3}$ monoclonal antibodies (clone B3A, MAB2023Z, and clone LM609, MAB1976Z, respectively; Chemicon) (data not shown). The $\alpha_{\mathrm{v}} \beta_{6}$ preparation was ca. 50 to $70 \%$ pure with some contaminating smaller-molecular-size (ca. 60 to $50 \mathrm{kDa}$ on nonreducing sodium dodecyl sulfate-polyacrylamide gel electrophoresis) impurities (data not shown).

In vitro binding of CAV9 to purified integrins. $\alpha_{v} \beta_{3}$ and $\alpha_{v} \beta_{6}$ binding assays were performed on Maxisorb 96-well plates (Nunc, Inc.). These were coated with approximately $300 \mathrm{ng}$ of $\alpha_{\mathrm{v}} \beta_{6} /$ well, purified as described above (quantified by spectroscopy), or with $\alpha_{v} \beta_{3}$ (Chemicon) by incubating overnight at $4^{\circ} \mathrm{C}$ in $150 \mu \mathrm{l}$ of TBS (pH 7.4) containing $1 \mathrm{mM} \mathrm{MgCl}_{2}, 1 \mathrm{mM} \mathrm{MnCl}_{2}$, and $2 \mathrm{mM} \mathrm{CaCl}_{2}$. The wells were then blocked with $100 \mu$ l of the coating buffer supplemented with $2 \%$ bovine serum albumin (BSA) for $2 \mathrm{~h}$ at room temperature. For virus binding, different amounts of purified CAV9 were applied to the wells and were incubated for $1 \mathrm{~h}$. All binding and inhibition experiments were done in $100 \mu \mathrm{l}$, and for binding the coating TBS buffer was supplemented with $0.1 \%$ BSA. Between steps the wells were washed three times with this buffer. Binding was detected by using a 1:500 dilution of rabbit antiserum against CAV9 and mouse anti-rabbit immunoglobulin $\mathrm{G}$ horseradish peroxidase-conjugated secondary antibody $(1: 1,000$ dilution; DAKO). Substrate conversion by horseradish peroxidase was detected at $492 \mathrm{~nm}$ after $30 \mathrm{~min}$ of incubation in the dark at room temperature, and the reaction was stopped by the addition of $200 \mu \mathrm{l}$ of $1 \mathrm{M} \mathrm{H}_{2} \mathrm{SO}_{4}$. To study peptide blocking of $\alpha_{v} \beta_{3}$-CAV9 binding, $90 \mu \mathrm{l}$ of binding buffer containing the peptide was mixed with $10 \mu \mathrm{l}$ of the virus and was incubated with the immobilized integrin. To enhance the poor peptide blocking effect on $\alpha_{v} \beta_{6}$-CAV9 binding, the integrin was preincubated for $30 \mathrm{~min}$ with peptide in a volume of $90 \mu \mathrm{l}$, followed by the addition of $10 \mu \mathrm{l}$ of virus and $1 \mathrm{~h}$ of incubation.

Flow cytometry analysis. Flow cytometry was performed as described previously (20). Briefly, cells were harvested with EDTA and were resuspended at $\sim 1$ $\times 10^{7}$ cells per $\mathrm{ml}$ in TBS, pH 7.4, containing $1 \mathrm{mM} \mathrm{CaCl}_{2}, 0.5 \mathrm{mM} \mathrm{MgCl}_{2}, 2 \%$ normal goat serum, and 3\% BSA (buffer A). Cells $(30 \mu \mathrm{l})$ were incubated sequentially with primary antibodies ( $10 \mu \mathrm{g}$ of cell suspension $/ \mathrm{ml}$ in buffer $\mathrm{A})$ on ice for $30 \mathrm{~min}$ followed by secondary antibodies conjugated with R-phycoerythrin (Southern Biotechnology Associates). The primary antibodies were against $\beta_{6}$, clone CS $\beta 6$ (MAB2076Z; Chemicon); $\alpha_{v} \beta_{3}$, clone LM609 (MAB1976Z; Chemicon); $\alpha_{\mathrm{v}} \beta_{5}$, clone P1F6 (MAB1961Z; Chemicon); and $\alpha_{5} \beta_{1}$, SAM-1 (Serotec). The cells were then washed and resuspended in $1 \%$ paraformaldehyde in phosphate-buffered saline. Background fluorescence was determined in the absence of the primary antibody. Fluorescent staining was analyzed by flow cytometry using a FACSCalibur (Becton Dickinson) counting 10,000 cells per sample.

Virus binding assay. Cells, prepared in buffer $\mathrm{A}$ as described above (supplemented with $1 \mathrm{mM} \mathrm{MnCl} 2)$, were incubated with purified CAV9 $(5 \mu \mathrm{g} / \mathrm{ml})$ for $1 \mathrm{~h}$ on ice, followed by addition of the anti-CAV9 monoclonal (MAB947; Chemicon) and a goat anti-mouse immunoglobulin G2b-specific, R-phycoerythrin conjugate. All steps were carried out in the presence of $1 \mathrm{mM}$ manganese. Background fluorescence was determined under two conditions: in the absence of the virus and in the absence of the anti-CAV9 monoclonal. Both background conditions gave near-identical results.

Plaque reduction assay using purified soluble $\boldsymbol{\alpha}_{\mathbf{v}} \boldsymbol{\beta}_{\mathbf{6}}$ integrin. GMK and RD cells, grown on 6-well plates, were infected with $100 \mu$ l of $2 \times 10^{2}$ PFU of CAV9 preincubated with serial dilutions of the soluble purified $\alpha_{v} \beta_{6}$ integrin for $30 \mathrm{~min}$ at $37^{\circ} \mathrm{C}$. The cells were washed with Hank's solution and were covered with $0.5 \%$ carboxymethyl cellulose in MEM supplemented with $1 \%$ FCS, glutamine, penicillin, and streptomycin. The cells were incubated for 2 days and were stained with crystal violet prior to counting plaques.

Virus blocking assays using anti- $\boldsymbol{\alpha}_{\mathbf{v}} \boldsymbol{\beta}_{\mathbf{6}}$ monoclonal antibody. RD and GMK cell monolayers in 24-well plates were washed with serum-free medium twice and then were incubated with 1.0 to $10 \mu \mathrm{g} / \mathrm{ml}$ of mouse anti-human $\alpha_{\mathrm{v}} \beta_{6}$ antibody (10D5; Chemicon) on a rocking plate at room temperature for $50 \mathrm{~min}$. After this time, $100 \mu \mathrm{l}$ of a $10^{4}-\mathrm{PFU} / \mathrm{ml}$ stock of virus was added to the wells. The monolayers were incubated under the same conditions for a further $50 \mathrm{~min}$. Two milliliters of plaque overlay medium $(0.5 \%$ carboxymethyl cellulose in growth medium) was added to each well, and the plates were incubated at $37^{\circ} \mathrm{C}$ with $6 \%$ $\mathrm{CO}_{2}$ for 2 to 3 days. The monolayers were then washed with phosphate-buffered saline and were stained with $0.1 \%$ crystal violet.

Growth of CAV9 on SW480 cells expressing integrin $\boldsymbol{\beta}_{6}$ and $\boldsymbol{\beta}_{3}$ subunits. CAV9 and the RGD deletion mutant D4 $\left(10^{5} \mathrm{PFU} / \mathrm{ml}\right)$ were adsorbed to confluent monolayers of mock-, $\beta_{3^{-}}$, and $\beta_{6}$-transfected SW480 cells on a rocking plate at room temperature for $1 \mathrm{~h}$ before they were incubated at $37^{\circ} \mathrm{C}$. Seventytwo hours postinfection cells were freeze-thawed three times, and plaque assays were carried out on the freeze-thawed suspensions.

\section{RESULTS}

CAV9 binds to purified integrin $\boldsymbol{\alpha}_{\mathbf{v}} \boldsymbol{\beta}_{\mathbf{6}}$. To investigate the potential of $\alpha_{v} \beta_{6}$ as a CAV9 receptor, we used a solid-phase assay to analyze the binding of CAV9 to the purified integrin. We included $\alpha_{\mathrm{v}} \beta_{3}$ in these experiments because this integrin has previously been shown to act as a CAV9 receptor (37). The results (Fig. 1) showed that CAV9 binds efficiently to both integrins in vitro. When $10 \mathrm{mM}$ EDTA was added to the binding buffer, CAV9 did not bind to either integrin, in agreement with the expected metal ion dependence of RGD-integrin receptors.

The specificity of the CAV9-integrin interaction was further studied in blocking experiments by using synthetic peptides (Fig. 2). Four different peptides were used: an RGD-containing peptide (GRGDSP) and its RGE-containing derivative (GRGESP); an RGD-containing peptide based on the CAV9 VP1 C terminus (QSRRRGDMST); and an unrelated control peptide (NGKKKNWKKIM) based on part of the human parechovirus 1 (HPeV1) VP3 sequence. Figure 2A shows that both of the RGD-containing peptides inhibit binding of CAV9 to $\alpha_{\mathrm{v}} \beta_{3}$ in a dose-dependent manner and that GRGDSP is a more potent inhibitor than the CAV9-derived peptide. The inhibitory effect of these peptides was specific, because the control peptides had no effect on virus binding. Similarly, both of the RGD peptides were found to inhibit CAV9 binding to $\alpha_{v} \beta_{6}$, although these peptides were less effective than $\alpha_{v} \beta_{3}$ because a higher peptide concentration was required to inhibit virus binding (Fig. 2B). In the case of $\alpha_{v} \beta_{6}$, to demonstrate a blocking effect it was necessary to preincubate the integrin and peptide prior to adding the virus. In contrast to $\alpha_{\mathrm{v}} \beta_{3}$, the CAV9 VP1-derived peptide was more efficient than GRGDSP 
$\mathbf{A}$

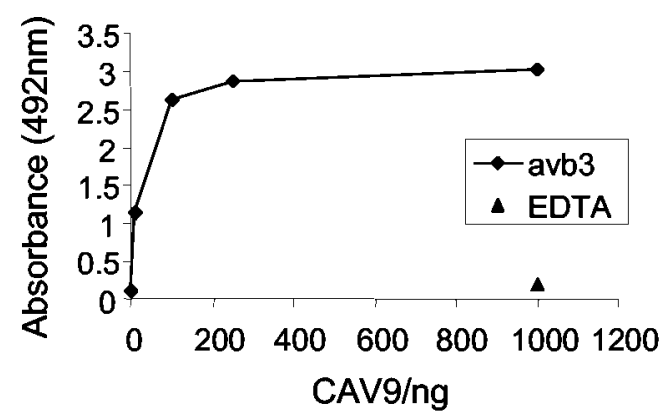

B

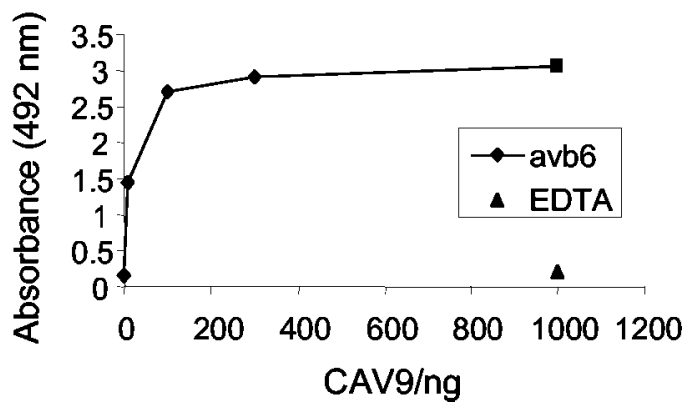

FIG. 1. In vitro binding of CAV9 to integrins $\alpha_{\mathrm{v}} \beta_{3}$ and $\alpha_{\mathrm{v}} \beta_{6}$ (A) CAV9 binding to integrin $\alpha_{v} \beta_{3}$. (B) CAV9 binding to integrin $\alpha_{v} \beta_{6}$. In each case 10 to $1,000 \mathrm{ng}$ of virus was applied to wells coated with approximately $300 \mathrm{ng}$ of receptor. Each data point is the average of duplicate measurements. There is no binding in the presence of EDTA (1,000 ng of virus tested).

as an inhibitor of virus binding to $\alpha_{\mathrm{v}} \beta_{6}$ and the VP3 control peptide had a partial effect on virus binding.

CAV9 binds to cells transfected with the integrin $\beta_{6}$-subunit gene. The above data show that CAV9 binds to $\alpha_{\mathrm{v}} \beta_{6}$ in an authentic cation- and RGD-dependent manner. We next tested whether it can also recognize this integrin on the cell surface. For these studies we used the human colon carcinoma cell line SW480, stably transfected to express either human $\alpha_{\mathrm{v}} \beta_{6}$ or $\alpha_{\mathrm{v}} \beta_{3}$ (Fig. 3A). Because manganese (Mn) ions are known to enhance ligand binding to several integrins, including $\alpha_{v} \beta_{3}(18,20,21,28,40)$, these experiments were carried out in the presence of $1 \mathrm{mM} \mathrm{Mn}$ ions (see Materials and Methods). These studies showed that CAV9 binds only to SW480 cells expressing $\alpha_{\mathrm{v}} \beta_{6}\left(\mathrm{SW} 480-\alpha_{\mathrm{v}} \beta_{6}\right)$ and not to the mock-transfected cells (SW480-mock) or to cells expressing $\alpha_{\mathrm{v}} \beta_{3}$ (SW480$\left.\alpha_{\mathrm{v}} \beta_{3}\right)$.

Infection of $S W 480-\alpha_{v} \beta_{6}$ and $S W 480-\alpha_{v} \beta_{3}$ cells by CAV9. We next determined whether the increase in CAV9 binding to SW480 cells expressing $\alpha_{\mathrm{v}} \beta_{6}$ results in a productive infection. SW480-mock, SW480- $\alpha_{\mathrm{v}} \beta_{6}$, and SW480- $\alpha_{\mathrm{v}} \beta_{3}$ cells were infected with CAV9, and the level of virus present at $72 \mathrm{~h}$ postinfection was determined by plaque assay. Figure 3B shows that infection of $S W 480-\alpha_{v} \beta_{6}$ cells results in an increased level of CAV9 over the input virus, but this is not seen in mock- and $\beta_{3}$-transfected cells. To confirm the role of the RGD motif in infection of SW480- $\alpha_{v} \beta_{6}$, we also infected these cells with the RGD-less CAV9 mutant, D4. No significant increase in the level of D4 was seen following infection of any of the cell lines.

GMK cells express $\boldsymbol{\alpha}_{\mathbf{v}} \boldsymbol{\beta}_{\mathbf{6}}$. GMK cells have been used extensively in studies on CAV9, as this virus grows efficiently on
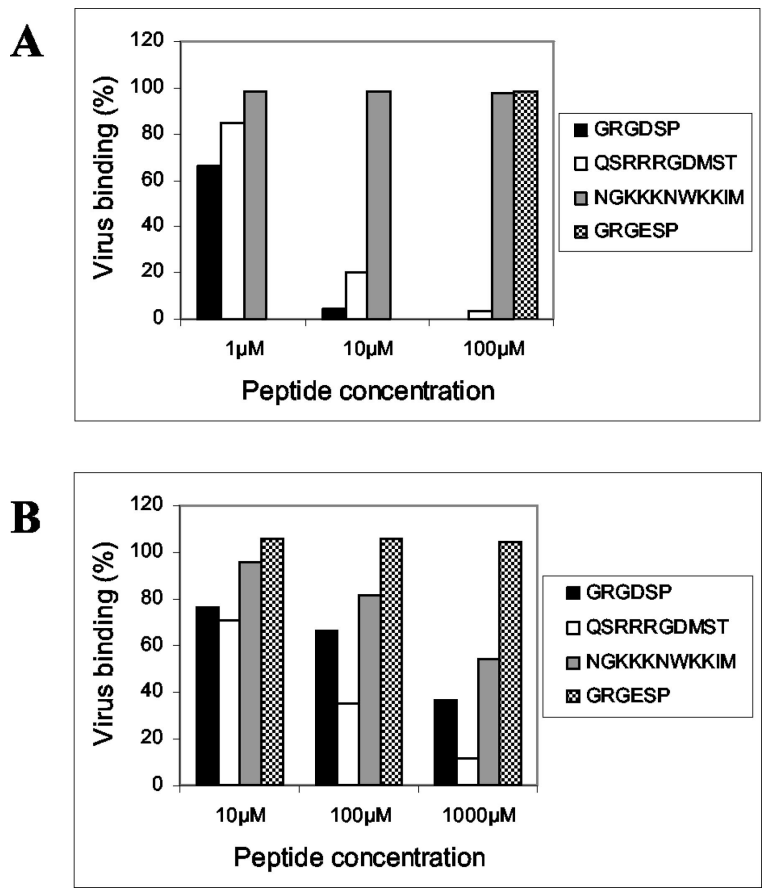

FIG. 2. Inhibition of CAV9 binding to purified integrins $\alpha_{\mathrm{v}} \beta_{3}$ and $\alpha_{v} \beta_{6}$ by RGD peptides. (A) CAV9 binding to integrin $\alpha_{v} \beta_{3}$. (B) CAV9 binding to integrin $\alpha_{v} \beta_{6}$. The peptides used were GRGDSP, GRGESP*, QSRRRGDMST (based on the CAV9 VP1 C terminus), and NGKKKNWKKIM (a control peptide based on part of the HPeV1 VP3 protein). The $y$ axis represents binding in the presence of the appropriate peptide as a percentage of binding without added peptide. The GRGESP peptide was used only at a concentration of 100 $\mu \mathrm{M}$ in the $\alpha_{\mathrm{v}} \beta_{3}$ experiment.

these cells in an RGD-dependent manner. Therefore, we used specific antibodies to determine the RGD-binding integrins expressed on GMK cells. Flow cytometric analysis indicated that GMK cells express the RGD-binding integrins, $\alpha_{5} \beta_{1}, \alpha_{v} \beta_{3}$, $\alpha_{v} \beta_{5}$, and the $\beta_{6}$ subunit. Because the $\beta_{6}$ subunit is normally expressed at the cell surface only when associated with the $\alpha_{\mathrm{v}}$ chain, these data indicate that GMK cells express $\alpha_{\mathrm{v}} \beta_{6}$ (Fig. 4).

Blocking of infection of susceptible cells by antibody to $\boldsymbol{\alpha}_{\mathbf{v}} \boldsymbol{\beta}_{\mathbf{6}}$. We then investigated whether $\alpha_{\mathrm{v}} \beta_{6}$ is used as a receptor to initiate CAV9 infection of GMK cells. Infection-blocking assays with an anti- $\alpha_{\mathrm{v}} \beta_{6}$ monoclonal antibody (10D5) revealed that CAV9 infection of GMK cells (Fig. 5A) is efficiently inhibited by this monoclonal antibody. By contrast, the antibody did not affect infection of GMK cells by D4 (Fig. 5C) or of RD cells by CAV9 (Fig. 5B). An interaction between CAV9 and $\alpha_{v} \beta_{6}$ was further confirmed by an experiment using the purified preparation of soluble $\alpha_{\mathrm{v}} \beta_{6}$ to inhibit CAV9 infection in a plaque reduction assay. The preparation efficiently blocked CAV9 infection in a dose-dependent manner (Fig. 5D).

\section{DISCUSSION}

Infection by CAV9 appears to be mediated through at least two pathways, one dependent on and the other independent of its RGD motif $(15,36)$. To date, the RGD-recognizing integrin $\alpha_{v} \beta_{3}$ is the only integrin implicated as a receptor for CAV9 (37, 44). In contrast, although FMDV has also been reported to 

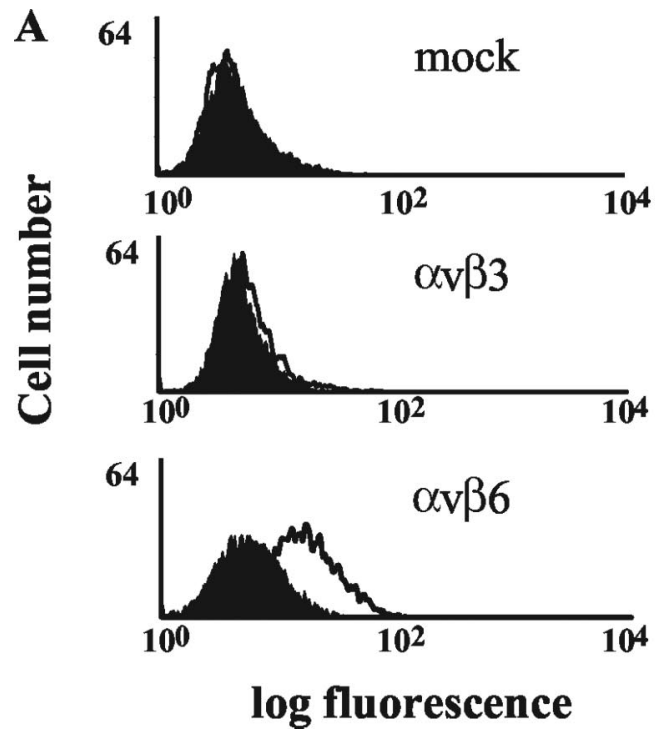

B

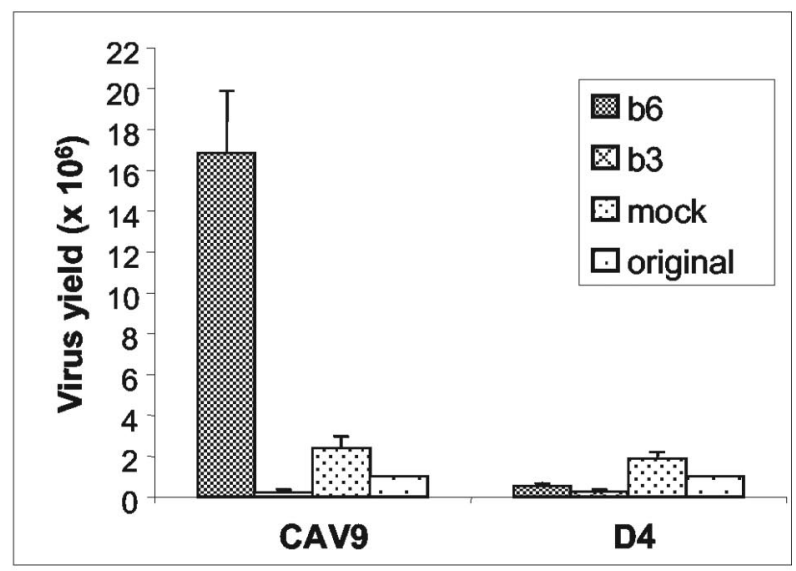

FIG. 3. Flow cytometric analysis of CAV9 binding to SW480 cells expressing $\alpha_{\mathrm{v}} \beta_{3}$ or $\alpha_{\mathrm{v}} \beta_{6}$ and enhanced growth of CAV9 in cells expressing $\alpha_{v} \beta_{6}$. (A) Control cell samples were processed in the absence of virus (filled histogram). Virus binding (open histogram) was detected on SW480- $\alpha_{v} \beta_{6}$. Virus binding was not detected with SW480-mock or SW480- $\alpha_{v} \beta_{3}$ cells. (B) Levels (in PFU) of CAV9 and the RGD-less derivative D4 obtained when grown on monolayers of SW480- $\alpha_{v} \beta_{3}$ (b3), SW480- $\alpha_{v} \beta_{6}$ (b6), and SW480-mock (mock) cells for $72 \mathrm{~h}$. The input virus inoculum is also shown (labeled "original"). The results are an average of duplicate measurements.

recognize $\alpha_{\mathrm{v}} \beta_{3}(3)$, it additionally interacts with several other integrins, including $\alpha_{\mathrm{v}} \beta_{6}(18-21)$. The amino acid sequence immediately following the RGD tripeptide in CAV9 and FMDV is similar (see Introduction), which prompted us to investigate whether there is an interaction between $\alpha_{\mathrm{v}} \beta_{6}$ and CAV9. In the present study we have shown that $\alpha_{v} \beta_{6}$ is a receptor for CAV9. Several main findings support this conclusion. (i) CAV9 binds to purified $\alpha_{v} \beta_{6}$ in an authentic cationand RGD-dependent interaction. (ii) CAV9 binding to SW480 cells is greatly enhanced following transfection with $\beta_{6}$ cDNA, which allows expression of $\alpha_{v} \beta_{6}$ at the cell surface. (iii) Infection of SW480 cells is also enhanced by expression of $\beta_{6}$. This infection is also dependent on the VP1 RGD, because infection of SW480 cells by an RGD-deleted CAV9 mutant, D4,

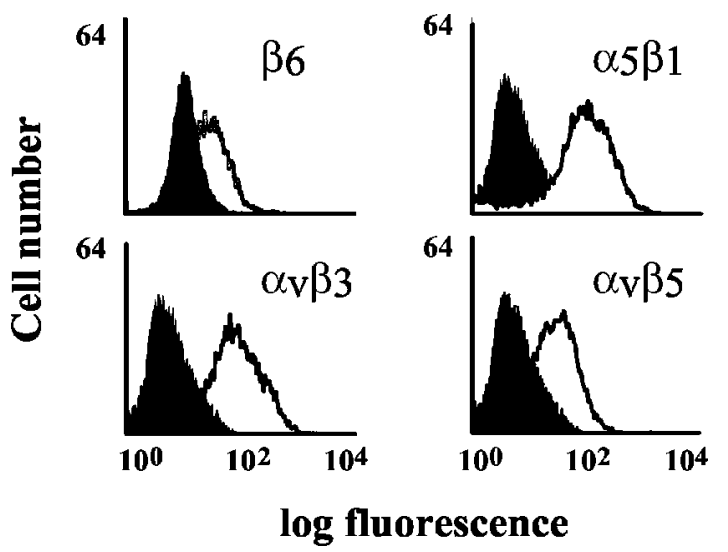

FIG. 4. Flow cytometric analysis of integrin expression on GMK cells. Cells were stained with integrin-specific monoclonal antibodies (open histogram) as indicated on the figure. Control cell samples were processed in the absence of the primary antibody (filled histogram). Antibodies: $\beta_{6}$, CS $\beta 6 ; \alpha_{\mathrm{v}} \beta_{3}, \mathrm{LM} 609 ; \alpha_{\mathrm{v}} \beta_{5}$, P1F6; and $\alpha_{5} \beta_{1}$, SAM-1. was not enhanced by $\alpha_{v} \beta_{6}$ expression. (iv) GMK cells express $\alpha_{v} \beta_{6}$, and infection of these cells by CAV9 is inhibited by a function-blocking monoclonal antibody to $\alpha_{\mathrm{v}} \beta_{6}$.

Our in vitro studies indicated that CAV9 can interact with purified $\alpha_{\mathrm{v}} \beta_{3}$ and $\alpha_{\mathrm{v}} \beta_{6}$ in a solid-phase assay (Fig. 1), and hence both can potentially act as a receptor for virus attachment to the host cell. In each case, binding is specific as it is reduced substantially by the addition of RGD-containing peptides (Fig. 2). These peptides were less effective in blocking CAV9 binding to $\alpha_{\mathrm{v}} \beta_{6}$, possibly suggesting that the CAV9$\alpha_{v} \beta_{6}$ interaction is of higher affinity. The generic peptide, GRGDSP, is a poor inhibitor of FMDV binding to $\alpha_{\mathrm{v}} \beta_{6}$ expressed on CHO cells (19), consistent with the weak effect this peptide had on the interaction between purified $\alpha_{\mathrm{v}} \beta_{6}$ and CAV9 (Fig. 2B).

In addition to binding to purified $\alpha_{v} \beta_{6}$, we showed by flow cytometry that CAV9 can also bind to SW480 cells expressing this integrin (Fig. 3A) (49). In contrast, CAV9 did not bind to mock-transfected SW480 cells lacking the $\beta_{6}$ subunit or to SW480 cells expressing $\alpha_{\mathrm{v}} \beta_{3}$. Binding differences of CAV9 to SW480- $\alpha_{\mathrm{v}} \beta_{6}$, SW480- $\alpha_{\mathrm{v}} \beta_{3}$, and SW480-mock cells were also reflected in the infection of these cells (Fig. 3B). CAV9 growth in SW480- $\alpha_{\mathrm{v}} \beta_{6}$ but not in SW480- $\alpha_{\mathrm{v}} \beta_{3}$ or SW480-mock cells gave a significant increase in yield over the input level. In contrast, the RGD-deleted mutant D4 did not show discrimination between these cells, indicating that infection of SW480$\alpha_{\mathrm{v}} \beta_{6}$ is RGD-dependent. Thus, CAV9 binds to $\alpha_{\mathrm{v}} \beta_{6}$ in vitro, while expression of this integrin on the SW480 cell surface confers the ability to bind and be infected by CAV9. $\alpha_{\mathrm{v}} \beta_{6}$ can therefore act as a functional RGD-dependent CAV9 receptor.

It has been reported that infection of SW480- $\alpha_{v} \beta_{6}$ cells by another enterovirus, coxsackievirus B1 (CBV1), is enhanced relative to that of mock-transfected cells (1). This observation is enigmatic, as CBV1 does not contain an RGD motif and 


\section{A. GMK/CAV9 B. RD/CAV9 C. GMK/D4 D.}
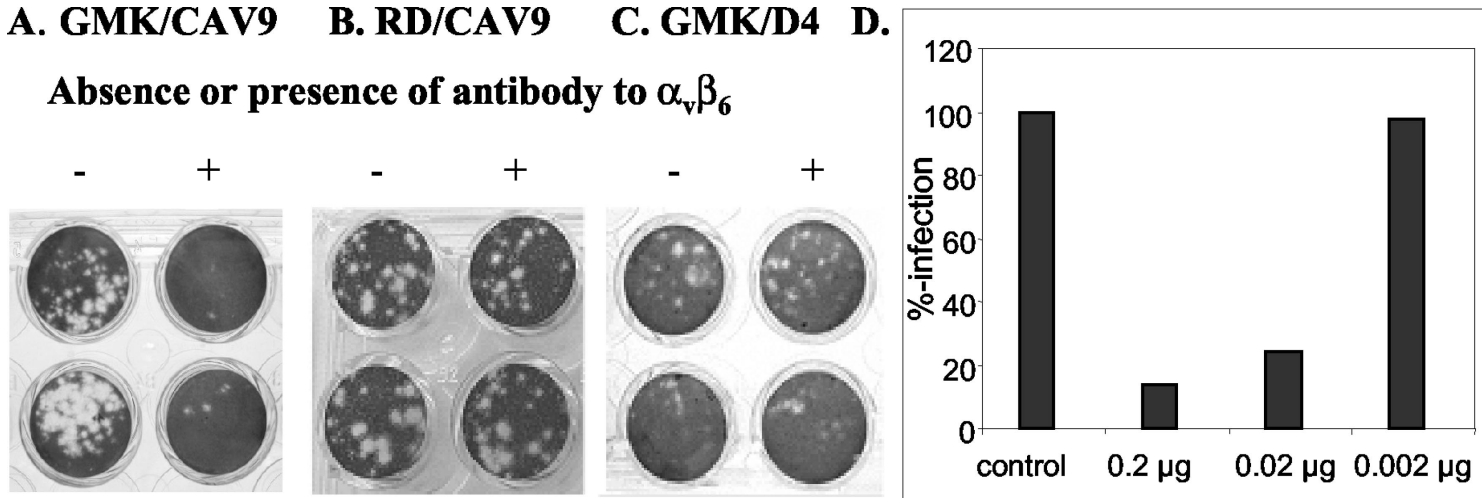

FIG. 5. Plaque reduction assays. (A to C) Blocking effect of an antibody to $\alpha_{\mathrm{v}} \beta_{6}$ (10D5) on the infection of cells by CAV9 and the RGD-less mutant D4. -, no antibody; +, $1.0 \mu \mathrm{g}$ of antibody. (A) CAV9 on GMK cells; (B) CAV9 on RD cells; (C) D4 on GMK cells. (D) Blocking of CAV9 infection in GMK cells by purified soluble $\alpha_{v} \beta_{6}$. Inhibition was measured by plaque reduction. Bars represent different amounts of $\alpha_{v} \beta_{6}$ incubated with CAV9 prior to addition to the cell monolayer.

therefore would not be expected to interact with $\alpha_{\mathrm{v}} \beta_{6}$ in the usual way. It is known that $\beta_{6}$-transfected cells have an increased growth rate, and this, or another effect on signaling, could alter the cellular environment and affect CBV1 replication (49). However, in our experiments D4 did not show increased infectivity of SW480- $\alpha_{v} \beta_{6}$ cells (Fig. 3B), so it seems more likely that enhanced infectivity of CAV9 is a direct effect arising from the use of $\alpha_{v} \beta_{6}$ as an RGD-dependent receptor.

The simian cell line GMK has been used extensively to study CAV9 infection $(15,36,37,44,47)$. We therefore investigated whether infection of this cell line could also be mediated by $\alpha_{v} \beta_{6}$. Flow cytometry showed that several RGD-recognizing integrins are present on GMK cells (Fig. 4). The level of $\alpha_{\mathrm{v}} \beta_{6}$ appears to be low but is significant, because a function-blocking $\alpha_{v} \beta_{6}$ antibody efficiently inhibited infection of GMK cells by CAV9 (Fig. 5A). It is, however, known that ligation and/or cross-linking of an integrin at the cell surface may activate intracellular signaling pathways that modulate the function of other integrin species expressed on the same cell in a process termed integrin cross-talk (4). Although we believe it unlikely, it is therefore possible that the effect of the anti- $\alpha_{\mathrm{v}} \beta_{6}$ monoclonal could be to downregulate the activity of other integrin molecules used by CAV9 on GMK cells rather than simple blocking of the $\alpha_{v} \beta_{6}$-RGD interaction. The fact that purified $\alpha_{v} \beta_{6}$ blocked infection in a dose-dependent manner (Fig. 5D) argues against this nonspecific effect.

The almost complete blocking of infection by anti- $\alpha_{\mathrm{v}} \beta_{6}$ suggests that $\alpha_{\mathrm{v}} \beta_{6}$ is the major receptor used by CAV9 to initiate infection of GMK cells. Other RGD-recognizing integrins expressed on these cells, including $\alpha_{\mathrm{v}} \beta_{3}$, may not be as important in entry, although the residual levels of infectivity may be due to interaction with other integrins. In this connection, it is interesting that the previously reported levels of blocking of CAV9 infection by $\alpha_{\mathrm{v}} \beta_{3}$ antibodies (around 50\%) $(44,47)$ are much less than that observed here for anti- $\alpha_{v} \beta_{6}$. Despite this relatively weak effect on infection, $\alpha_{v} \beta_{3}$ antibodies can compete with CAV9 for binding to GMK cells, while expression of $\alpha_{\mathrm{v}} \beta_{3}$ on $\mathrm{CHO}$ cells makes these cells susceptible to CAV9 binding and infection (44), suggesting that $\alpha_{\mathrm{v}} \beta_{3}$ can act as a functional receptor in both these cell lines. The failure to infect
SW480- $\alpha_{\mathrm{v}} \beta_{3}$ cells is therefore surprising, given that SW480$\alpha_{v} \beta_{6}$ cells were infected. It is likely that more than one molecule is required for CAV9 entry, and GRP78, $\beta_{2}$-microglobulin, and major histocompatibility complex class I have been implicated in other cells $(44,47,48)$, while we have observed that some CAV9 strains can utilize heparan sulfate (unpublished data). One possibility is that SW480- $\alpha_{v} \beta_{3}$ cells do not possess the full repertoire of cofactors required for a productive infection mediated by $\alpha_{v} \beta_{3}$ entry, while these cofactors are present on GMK and CHO cells. An absence of a critical factor could potentially prevent virus binding if it were to lead to a subtle alteration in protein conformation, and this may explain the disparity between the in vitro binding of CAV9 to $\alpha_{v} \beta_{3}$ and the lack of binding to SW480- $\alpha_{v} \beta_{3}$ cells. Surprisingly, given that $\alpha_{\mathrm{v}} \beta_{3}$ is considered an RGD-dependent integrin, binding of CAV9 to $\mathrm{CHO}$ cells expressing $\alpha_{v} \beta_{3}$ is not dependent on the RGD motif, because an RGDless mutant can still bind to these cells (46). This RGD independence contrasts with the RGD-dependent infectivity of SW480- $\alpha_{\mathrm{v}} \beta_{6}$ cells by CAV9 (Fig. 3) and may contribute to the apparent difference in functionality of $\alpha_{v} \beta_{3}$ expressed on SW480 and CHO cells.

The data presented here provide the first evidence that integrin $\alpha_{v} \beta_{6}$ is a receptor for CAV9. This is interesting in light of the observed sequence similarity between the regions surrounding the RGD motifs of CAV9 and latent TGF- $\beta_{1}$, a ligand for $\alpha_{\mathrm{v}} \beta_{6}$ (31), although TGF- $\beta 1$ has also been reported to interact with $\alpha_{\mathrm{v}} \beta_{1}, \alpha_{\mathrm{v}} \beta_{8}$, and $\alpha_{8} \beta_{1}(25,29,30)$. This may suggest that $\alpha_{\mathrm{v}} \beta_{6}$ is an important receptor for CAV9 in natural infections as well as in the cell lines tested here. The RGD motif is a feature of all natural isolates of CAV9, although specific mutants lacking it can be generated in the laboratory (7, 15, 39). These grow less well than their RGD-containing parent in many cell lines and show reduced pathogenicity in a mouse model $(12,13,15)$. While previous studies have related the function of the RGD motif only to interactions with the integrin $\alpha_{\mathrm{v}} \beta_{3}$, we have shown here that CAV9 can also interact with $\alpha_{v} \beta_{6}$ and that this interaction is biologically relevant. This is consistent with the expression of $\alpha_{\mathrm{v}} \beta_{6}$ on epithelial cells, the initial site of enterovirus infection. 


\section{ACKNOWLEDGMENTS}

The studies were supported by grants from the Wellcome Trust, the Academy of Finland, and the Sigrid Juselius Foundation.

We thank Maaria Vainio for excellent technical assistance and Merja Roivainen (KTL, Helsinki, Finland) and Jyrki Heino (University of Jyväskylä, Finland) for the kind gift of integrin antibodies.

\section{REFERENCES}

1. Agrez, M. V., D. R. Shafren, X. Gu, K. Cox, D. Sheppard, and R. D. Barry. 1997. Integrin alpha $v$ beta 6 enhances coxsackievirus B1 lytic infection of human colon carcinoma cells. Virology 239:71-77.

2. Baranowski, E., C. M. Ruiz-Jarabo, N. Sevilla, D. Andreu, E. Beck, and E. Domingo. 2000. Cell recognition by foot-and-mouth disease virus that lacks the RGD integrin-binding motif: flexibility in aphthovirus receptor usage. J. Virol. 74:1641-1647.

3. Berinstein, A., M. Roivainen, T. Hovi, P. W. Mason, and B. Baxt. 1995. Antibodies to the vitronectin receptor (integrin $\alpha_{\mathrm{v}} \beta_{3}$ ) inhibit binding and infection of foot-and-mouth-disease virus to cultured-cells. J. Virol. 69:2664 2666.

4. Blystone, S. D., S. E. Slater, M. P. Williams, M. T. Crow, and E. J. Brown. 1999. A molecular mechanism of integrin crosstalk: $\alpha_{v} \beta_{3}$ suppression of calcium/calmodulin-dependent protein kinase II regulates $\alpha_{5} \beta_{1}$ function. J. Cell Biol. 145:889-897.

5. Boonyakiat, Y., P. J. Hughes, F. Ghazi, and G. Stanway. 2001. Arginineglycine-aspartic acid motif is critical for human parechovirus 1 entry. J. Virol. 75:10000-10004.

6. Chang, K. H., P. Auvinen, T. Hyypiä, and G. Stanway. 1989. The nucleotide sequence of coxsackievirus A9-implications for receptor binding and enterovirus classification. J. Gen. Virol. 70:3269-3280.

7. Chang, K. H., C. Day, J. Walker, T. Hyypiä, and G. Stanway. 1992. The nucleotide sequences of wild-type coxsackievirus A9 strains imply that an RGD motif in VP1 protein is functionally significant. J. Gen. Virol. 73:621626.

8. Escarmis, C., E. C. Carrillo, M. Ferrer, J. F. G. Arriaza, N. Lopez, C. Tami, N. Verdaguer, E. Domingo, and M. T. Franze-Fernandez. 1998. Rapid selection in modified BHK-21 cells of a foot-and-mouth disease virus varian showing alterations in cell tropism. J. Virol. 72:10171-10179.

9. Evans, D. J., and J. W. Almond. 1998. Cell receptors for picornaviruses as determinants of cell tropism and pathogenesis. Trends Microbiol. 6:198-202.

10. Ghazi, F., P. J. Hughes, T. Hyypiä, and G. Stanway. 1998. Molecular analysis of human parechovirus type 2 (formerly echovirus 23). J. Gen. Virol. 79: $2641-2650$.

11. Grist, N. R., and D. Reid. 1988. General pathogenicity and epidemiology, p. 221-239. In M. Berdinelli and H. Friedman (ed.), Coxsackieviruses: a general update, Plenum Press, New York, N.Y.

12. Harvala, H., H. Kalimo, L. Dahllund, J. Santti, P. J. Hughes, T. Hyypiä, and G. Stanway. 2002. Mapping of tissue tropism determinants in coxsackievirus genomes. J. Gen. Virol. 83:1697-1706.

13. Harvala, H., H. Kalimo, G. Stanway, and T. Hyypiä. 2003. Pathogenesis of coxsackievirus A9 in mice: role of the viral arginine-glycine-aspartic acid motif. J. Gen. Virol. 84:2375-2379.

14. Hendry, E., H. Hatanaka, E. Fry, M. Smyth, J. Tate, G. Stanway, J. Santti, M. Maaronen, T. Hyypiä, and D. Stuart. 1999. The crystal structure of coxsackievirus A9: new insights into the uncoating mechanisms of enteroviruses. Structure 7:1527-1538

15. Hughes, P. J., C. Horsnell, T. Hyypiä, and G. Stanway. 1995. The coxsackievirus A9 RGD motif is not essential for virus viability. J. Virol. 69:80358040.

16. Hynes, R. O. 1992. Integrins: versatility, modulation, and signaling in cell adhesion. Cell 69:11-25.

17. Hyypiä, T., C. Horsnell, M. Maaronen, M. Khan, N. Kalkkinen, P. Auvinen, L. Kinnunen, and G. Stanway. 1992. A distinct picornavirus group identified by sequence analysis. Proc. Natl. Acad. Sci. USA 89:8847-8851.

18. Jackson, T., A. Sharma, R. Abu-Ghazaleh, W. E. Blakemore, F. M. Ellard, D. L. Simmons, J. W. I. Newman, D. I. Stuart, and A. M. Q. King. 1997. Arginine-glycine-aspartic acid-specific binding by foot-and-mouth disease viruses to the purified integrin $\alpha_{v} \beta_{3}$ in vitro. J. Virol. 71:8357-8361.

19. Jackson, T., A. P. Mould, D. Sheppard, and A. M. Q. King. 2002. Integrin $\alpha_{v} \beta_{1}$ is a receptor for foot-and-mouth disease virus. J. Virol. 76:935-941.

20. Jackson, T., D. Sheppard, M. Denyer, W. Blakemore, and A. M. Q. King. 2000. The epithelial integrin $\alpha_{v} \beta_{6}$ is a receptor for foot-and-mouth disease virus. J. Virol. 74:4949-4956.

21. Jackson, T., W. Blakemore, J. W. I. Newman, N. J. Knowles, A. P. Mould, M. J. Humphries, and A. M. Q. King. 2000. Foot-and-mouth disease virus is a ligand for the high-affinity binding conformation of integrin $\alpha_{5} \beta_{1}$ : influence of the leucine residue within the RGDL motif on selectivity of integrin binding. J. Gen. Virol. 81:1383-1391.

22. Joki-Korpela, P., M. Roivainen, H. Lankinen, T. Pöyry, and T. Hyypiä. 2000 Antigenic properties of human parechovirus 1. J. Gen. Virol. 81:1709-1718.
23. Joki-Korpela, P., V. Marjomäki, C. Krogerus, J. Heino, and T. Hyypiä. 2001. Entry of human parechovirus 1. J. Virol. 75:1958-1967.

24. Leippert, M., E. Beck, F. Weiland, and E. Pfaff. 1997. Point mutations within the $\beta \mathrm{G}-\beta \mathrm{H}$ loop of foot-and-mouth disease virus $\mathrm{O} 1 \mathrm{~K}$ affect virus attachment to target cells. J. Virol. 71:1046-1051.

25. Lu, M., J. S. Munger, M. Steadele, C. Busald, M. Tellier, and L. M. Schnapp. 2002. Integrin $\alpha_{8} \beta_{1}$ mediates adhesion to LAP-TGF $\beta_{1}$. J. Cell Sci. 115 $4641-4648$.

26. Mason, P. W., E. Rieder, and B. Baxt. 1994. RGD sequence of foot-andmouth disease virus is essential for infecting cells via the natural receptor but can be bypassed by an antibody-dependent enhancement pathway. Proc. Natl. Acad. Sci. USA 91:1932-1936.

27. Miller, L. C., W. Blakemore, D. Sheppard, A. Atakilit, A. M. Q. King, and T. Jackson. 2001. Role of the cytoplasmic domain of the $\beta$-subunit of integrin $\alpha_{v} \beta_{6}$ in infection by foot-and-mouth disease virus. J. Virol. 75:4158-4164.

28. Mould, A. P., S. K. Akiyama, and M. J. Humphries. 1995. Regulation of integrin $\alpha_{5} \beta_{1}$-fibronectin interactions by divalent cations. J. Biol. Chem. 270:26270-26277.

29. Mu, D. Z., S. Cambier, L. Fjellbirkeland, J. L. Baron, J. S. Munger, H. Kawakatsu, D. Sheppard, V. C. Broaddus, and S. L. Nishimura. 2002. The integrin $\alpha_{\mathrm{v}} \beta_{8}$ mediates epithelial homeostasis through MT1-MMP-dependent activation of TGF- $b_{1}$. J. Cell Biol. 157:493-507.

30. Munger, J. S., J. G. Harpel, F. G. Giancotti, and D. B. Rifkin. 1998. Interactions between growth factors and integrins: latent forms of transforming growth factor- $\beta$ are ligands for the integrin $\alpha_{v} \beta_{1}$. Mol. Biol. Cell. 9:26272638.

31. Munger, J. S., X. Z. Huang, H. Kawakatsu, M. J. D. Griffiths, S. L. Dalton, J. F. Wu, J. F. Pittet, N. Kaminski, C. Garat, M. A. Matthay, D. B. Rifkin, and D. Sheppard. 1999. The integrin $\alpha_{v} \beta_{6}$ binds and activates latent TGF $\beta_{1}$ : a mechanism for regulating pulmonary inflammation and fibrosis. Cell 96: 319-328.

32. Neff, S., D. Sa-Carvalho, E. Rieder, P. W. Mason, S. D. Blystone, E. J. Brown, and B. Baxt. 1998. Foot-and-mouth disease virus virulent for cattle utilizes the integrin $\alpha_{\mathrm{v}} \beta_{3}$ as its receptor. J. Virol. 72:3587-3594.

33. Neff, S., P. W. Mason, and B. Baxt. 2000. High-efficiency utilization of the bovine integrin $\alpha_{\mathrm{v}} \beta_{3}$ as a receptor for foot-and-mouth disease virus is dependent on the bovine $\beta_{3}$ subunit. J. Virol. 74:7298-7306.

34. Nelsen-Salz, B., H. J. Eggers, and H. Zimmermann. 1999. Integrin $\alpha_{v} \beta_{3}$ (vitronectin receptor) is a candidate receptor for the virulent echovirus 9 strain Barty. J. Gen. Virol. 80:2311-2313.

35. Pulli, T., E. Koivunen, and T. Hyypiä. 1997. Cell-surface interactions of echovirus 22. J. Biol. Chem. 272:21176-21180.

36. Roivainen, M., T. Hyypiä, L. Piirainen, N. Kalkkinen, G. Stanway, and T. Hovi. 1991. RGD-dependent entry of coxsackievirus A9 into host cells and its bypass after cleavage of VP1 protein by intestinal proteases. J. Virol. 65: $4735-4740$.

37. Roivainen, M., L. Piirainen, T. Hovi, I. Virtanen, T. Riikonen, J. Heino, and T. Hyypiä. 1994. Entry of coxsackievirus A9 into host cells: specific interactions with $\alpha_{v} \beta_{3}$ integrin, the vitronectin receptor. Virology 203:357-365.

38. Ruoslahti, E., and M. D. Pierschbacher. 1987. New perspectives in cell adhesion: RGD and integrins. Science 238:491-497.

39. Santti, J., H. Harvala, L. Kinnunen, and T. Hyypiä. 2000. Molecular epidemiology and evolution of coxsackievirus A9. J. Gen. Virol. 81:1361-1372.

40. Springer, T. A. 1990. Adhesion receptors of the immune system. Nature 346:425-434.

41. Stanway, G. 1990. Structure, function and evolution of picornaviruses. J. Gen. Virol. 71:2483-2501.

42. Stanway, G., N. Kalkkinen, M. Roivainen, F. Ghazi, M. Khan, M. Smyth, O. Meurman, and T. Hyypiä. 1994. Molecular and biological characteristics of echovirus $22-$ a representative of a new picornavirus group. J. Virol. 68: 8232-8238.

43. Stanway, G., T. Hovi, N. J. Knowles, and T. Hyypiä. 2002. Biological and molecular basis of picornavirus classification, p. 17-24. In B. L. Semler and E. Wimmer (ed.), Molecular biology of picornaviruses, ASM Press, Washington, D.C

44. Triantafilou, M., K. Triantafilou, K. M. Wilson, Y. Takada, N. Fernandez, and G. Stanway. 1999. Involvement of $\beta_{2}$-microglobulin and integrin $\alpha_{v} \beta_{3}$ molecules in the coxsackievirus A9 infectious cycle. J. Gen. Virol. 80:25912600 .

45. Triantafilou, K., M. Triantafilou, Y. Takada, and N. Fernandez. 2000. Human parechovirus 1 utilizes integrins $\alpha_{\mathrm{v}} \beta_{3}$ and $\alpha_{\mathrm{v}} \beta_{1}$ as receptors. J. Virol. 74:5856-5862

46. Triantafilou, M., K. Triantafilou, K. M. Wilson, Y. Takada, and N. Fernandez. 2000. High affinity interactions of coxsackievirus A9 with integrin alpha $v$ beta $3(\mathrm{CD} 51 / 61)$ require the CYDMKTTC sequence of beta 3 , but do not require the RGD sequence of the CAV-9 VP1 protein. Hum. Immunol. 61:453-459.

47. Triantafilou, K., D. Fradelizi, K. Wilson, and M. Triantafilou. 2002. GRP78, a coreceptor for coxsackievirus A9, interacts with major histocompatibility complex class I molecules which mediate virus internalization. J. Virol. 76:633-643.

48. Ward, T., R. M. Powell, P. A. Pipkin, D. J. Evans, P. D. Minor, and J. W. 
Almond. 1998. Role for $\beta_{2}$-microglobulin in echovirus infection of rhabdomyosarcoma cells. J. Virol. 72:5360-5365.

49. Weinacker, A., A. Chen, M. Agrez, R. I. Cone, S. Nishimura, E. Wayner, R. Pytela, and D. Sheppard. 1994. Role of the integrin alpha v beta 6 in cell attachment to fibronectin-heterologous expression of intact and secreted forms of the receptor. J. Biol. Chem. 269:6940-6948.

50. Zimmermann, H., H. J. Eggers, A. Zimmermann, W. Kraus, and B. Nelsen-Salz. 1995. Complete nucleotide sequence and biological proper- ties of an infectious clone of prototype echovirus 9. Virus Res. 39:311319.

51. Zimmermann, H., H. J. Eggers, and B. Nelsen-Salz. 1996. Molecular cloning and sequence determination of the complete genome of the virulent echovirus 9 strain Barty. Virus Genes 12:149-154.

52. Zimmermann, H., H. J. Eggers, and B. Nelsen-Salz. 1997. Cell attachment and mouse virulence of echovirus 9 correlate with an RGD motif in the capsid protein VP1. Virology 233:149-156. 